destined to generate considerable controversy in the scientific community, coinciding as they do with other indications that a concern for industrially relevant research may overshadow arguments about the need to devise a system for ensuring the maintenance of high scientific standards.

"It is a very dangerous step to take," says Lewis Moonie, the Labour Party's science spokesman. "The peer review system works fairly well, and something that works well should not be changed, while the purpose of the research councils is to fund basic research, not to plug the gaps caused by cutbacks elsewhere in the government's funding of applied research." David Dickson - Richard Brook, Cookson Professor of Materials Science and head of the department of material at Oxford University, has been appointed the first chief executive officer of the new Engineering and Physical Sciences Research Council.

Brook is a specialist in ceramics and their application to mechanical engineering, and is currently chairman of the SERC's materials commission, as well as vice-president of the Institute of Materials.

His appointment completes the government's team of new research councils' heads, each now having an industrialist as a parttime chairman, and an academic scientist as a full-time chief executive officer.

\section{Cancer geneticists sign deal with genome company}

Washington. A collaborative agreement has been signed by a research team led by Bert Vogelstein and Kenneth Kinzler at Johns Hopkins University, Maryland, and the gene sequencing company Human Genome Sciences (HGS).

The deal will give HGS exclusive licensing rights to the outcome of research carried out at Johns Hopkins into the connection between colon cancer and genes sequenced at both HGS and its non-profit associate, Craig Venter's Institute for Genomic Research.

William Haseltine, the chairman of HGS, says the deal is no different from the agreement which any laboratory would use to protect its intellectual property. But he adds that it is the first of many such agreements which HGS hopes to sign.

Vogelstein - the top-cited scientist of 1993, primarily for his work on the genetic basis of cancer, according to statistics compiled by the Philadelphia-based newsletter ScienceWatch in which Kinzler was second — is reluctant to give further details about the deal. He says that its significance will become clearer when research connected with it, which is already completed and has been submitted to a US journal, is published.

c. $\mathbf{M}$.

\title{
Fiscal limits cut impact of Clinton's technology dream
}

Washington. Al Gore, the US vice-president, last week launched a joint research and development initiative between the federal government and the US semiconductor industry which, he said, would be "of an entirely different order of magnitude" to similar activities already underway.

But the details of the initiative, which will involve the departments of defence, energy and commerce, suggest that it is likely to have a relatively small impact compared to that of the $\$ 4.5$ billion which the US semiconductor industry already spends each year on research.

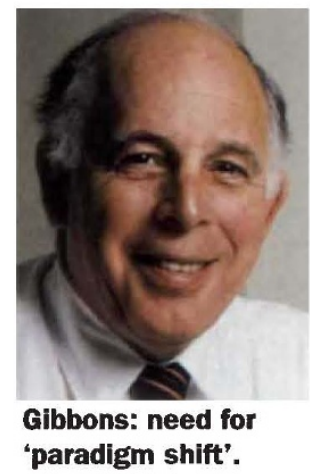

Apart from cre-

ating yet another Washington oversight board - the Semiconductor Technology Council - the initiative will have three substantive elements, one old and two new.

The largest element will come from the Department of Defense, which will continue to invest about $\$ 90$ million a year in Sematech This is a collaboration between government and industry which, despite much criticism, has been running since 1987 , and has lately focused on helping US companies build the machines to make microchips.

This effort will now be complemented by the Department of Energy (DOE), which will spend around $\$ 50$ million over the next five years on a centre to help the microchip industry with computer simulation. The Department of Commerce will provide up to $£ 25$ million over this period through the National Institute of Standards and Technology (NIST) for a metrology centre to help the industry measure tiny distances. In each case, industry is expected to match the government's investment.

The new initiative has been generally welcomed by the electronics industry. But, as the US government slowly begins to steer its $\$ 72$ billion research budget away from fundamental science towards applied research, the key question remains whether initiatives of this type will actually produce significant economic benefits.

Last week, top managers from the industry who had gathered in Washington to help launch the new initiative praised Sematech's track record, and dutifully pledged that the advantages promised by Gore from the additional efforts will be forthcoming.

Craig Barrett, chief executive of Intel and president of the Semiconductor Indus- try Association, said Sematech had helped his industry "to pull itself together" in the face of the Japanese threat in the late 1980s. He added that the new deal would prove "as vital an influence as Sematech was over the last five years."

But few view Sematech as pivotal in the turnaround achieved by the US industry, which last year overtook Japan as market leaders for the first time since 1985. Sematech itself encountered problems early in its life, and some members pulled out as its original goal of getting rival firms to co-operate on chip development proved unrealistic.

The collaboration has since become more narrowly defined, concentrating on semiconductor manufacturing equipment, and is widely credited in the industry with improving the quality of such equipment built in the United States.

But if the administration really wanted to expand the Sematech model into a substantial inter-agency partnership, fiscal constraints seem to have prevented it from doing so. In practice, the amount of new money is trivial compared with the overall research and development budgets of the industry.

Despite funding restrictions, administration officials claim the new initiative will still have a significant impact. "We want to strengthen a partnership which has already become profound," Jack Gibbons, the president's science advisor, said last week.

Gibbons says that the semiconductor industry "is facing challenges which may call for a paradigm shift". As chips get smaller, he adds, "engineers will have to know quantum mechanics that were previously only of interest to physicists".

Energy secretary Hazel O'Leary said that the initiative differed from previous policy both in its multi-agency nature, and in the spirit in which it was entered into. "In the past five years it was a reluctant partnership," she said. "We are attesting to the fact that we like this partnership, and we need others like it." Although O'Leary talked of selecting a site for the DoE computer simulation centre, officials said the money was likely to be divided between the department's Sandia, Los Alamos and Lawrence Livermore laboratories.

The administration's hope is that the centres to be set up by NIST and the DoE will successfully focus on small niches which the industry might otherwise neglect.

Furthermore, the semiconductor industry may be feeling that, however hollow the idea of a 'research partnership' with government, a public expression of gratitude is a small price to pay for favours it has received elsewhere, for example in trade negotiations with the Japanese.

Colin Macilwain 